\title{
ASSESSING THE IMPACT OF USING FUELS MADE FROM VEGETABLE OIL ON SELECTED OPERATIONAL VEHICLE CHARACTERISTICS
}

\begin{abstract}
Vegetable oil based fuels significantly enable reducing the costs of fuel purchased. CI engine vehicles with rotary and inline injection pump can be fuelled by vegetable oil based fuels instead of being fuelled by diesel. This is very common, since their price is lower in comparison with diesel. The article focuses on the impact of using fuels made from vegetable oil on selected vehicle characteristics in particular conditions. It includes the measurements of the impact of using fuels such as FAME, fresh oil and used oil on the engine smoke opacity, content of selected emissions in the exhaust gases as well as on the engine power and torque's course. The measurement results are mutually compared with the results measured when using diesel. In order to secure the measurements to be repeatable, they were performed in laboratory at the cylinder test station MAHA MSR 1050. The vehicle tested during its last 100,000 kilometres driven by vegetable oil based fuel has been selected for these measurements. Therefore, by these measurements, it was also possible to assume partially the impact of long-term using aforesaid fuels on selected vehicle characteristics.
\end{abstract}

Keywords: emissions, FAME, fuel, engine power, vegetable oil,

\section{František Synák ${ }^{1}$}

${ }^{1}$ Faculty of Operational and Economics of Transport and Communications, University of Žilina, Univerzitná 1, Žilina, +42141513 3518,frantisek.synak@fpedas.uniza.sk

Marcel Frančák ${ }^{2}$

${ }^{2}$ Faculty of Operational and Economics of Transport and Communications, University of Žilina, Univerzitná 1, Žilina, +421 41513 3523, marcel.francak@fpedas.uniza.sk

Tomáš Skrúcaný ${ }^{3}$

${ }^{3}$ Faculty of Operational and Economics of Transport and Communications, University of Žilina, Univerzitná 1, Žilina, +421 41513 3518, tomas.skrucany@fpedas.uniza.sk

Vladimír Rievaj ${ }^{4}$

${ }^{4}$ Faculty of Operational and Economics of Transport and Communications, University of Žilina, Univerzitná 1, Žilina, +421 41513 3532,vladimir.rievaj@fpedas.uniza.sk

\section{Introduction}

Most of the costs for an operation of vehicle are those of purchases of fuel (Synák, 2019). Part of the owners of agricultural machineries and tractors as well as vehicles with CI engines reduces the costs of fuel purchased by using fuels produced on the basis of vegetable oil. These include oils such as FAME, fresh vegetable oil and used vegetable oil (Mohadesi et al., 2019).

FAME, i.e. fatty acid methyl ester, is a fuel of natural origin. It can be made from used vegetable oil by removing glycerol molecule. This is further followed by transesterification of fats with methanol. The production of FAME is also possible at home. The price per litre of FAME depends specially on the vegetable oil's purchase price. Production costs of FAME made from 1 litre of oil used are approximately of $0.13 €$ (Karimi et al., 2016).

Fresh oil represents an oil of natural origin made from sunflower or oilseed rape. The vegetable oil can be bought from about $0.70 € / 1$ (komodityonline). It is not processed in any way before being used in a vehicle.

Used oil represents a type of oil used when cooking meals, most often when frying. It is necessary to be filtered through a sieve or gauze before being used in a vehicle.
When comparing the costs of diesel fuel and fuels made from vegetable oil, it leads the drivers to use fuels made from vegetable oil (globalpetrolprices).

The purpose of this article is to compare the impact of using selected fuels made from vegetable oil and diesel on several aspects of vehicle operation under specific conditions. The article contains the results of measuring the impact of fuels made from vegetable oil on the engine smoke opacity, exhaust gases volume composition from the harmful emissions point of view and, on the course of the engine power and torque's curves depending on the engine speed. Each of the measurements was performed with using diesel fuel, FAME, fresh vegetable oil and used oil.

Since the engine smoke opacity is regularly measured during a vehicle inspection, it is also measured in this article. Therefore, the purpose is to determine whether a vehicle fuelled by selected fuel meets the requirements for smoke opacity value that is verified during vehicle emission inspection.

Exhaust gases volume from the emission point of view focuses on the presence of $\mathrm{CO}, \mathrm{CO}_{2}, \mathrm{HC}$ and $\mathrm{NO}_{\mathrm{x}}$.

$\mathrm{CO}$, i.e. carbon monoxide, is produced from the partial oxidation of carbon. CO has an adverse effect on human health. It binds with haemoglobin 300 times stronger than oxygen, and so it prevents oxygen from its transfer from lungs into organism. $\mathrm{CO}$ has a share in 
increasing premature mortality of population (Šarkan et al., 2016).

$\mathrm{CO}_{2}$, carbon dioxide, is a greenhouse gas. Its share in the greenhouse effect is more than $50 \%$ (Škorupa et al., 2018).

UHCs, unburned hydrocarbons, are products of incomplete combustion of fuel in an engine. Hydrocarbons irritate the human mucous membranes and some of them are carcinogenic (Shim et al., 2018).

$\mathrm{NO}_{\mathrm{x}}$, nitrogen oxides, are produced in the engine combustion area at higher pressures and temperatures. These conditions are fulfilled mainly by CI engines (Synák et al., 2018). Nitric oxide (NO), nitrogen dioxide $\left(\mathrm{NO}_{2}\right)$, nitrous oxide $\left(\mathrm{N}_{2} \mathrm{O}\right)$ together with dinitrogen trioxide $\left(\mathrm{N}_{2} \mathrm{O}_{3}\right)$ and dinitrogen pentoxide $\left(\mathrm{N}_{2} \mathrm{O}_{5}\right)$ are produced during the period at which an engine works in the above mentioned conditions. $\mathrm{NO}_{\mathrm{x}}$ have adverse effects on human health as well as on the greenhouse effect. They also cause acid rain (Skrúcaný et al., 2018).

In order to start measuring, a vehicle with $\mathrm{CI}$ engine fuelled its last 100,000 kilometres by vegetable oil based fuel has been chosen. By measuring the engine power and torque, it was possible to find out whether the engine can have a power and torque prescribed by the manufacturer.

\section{Measurement methodology}

The measurements included measuring the smoke opacity, exhaust gases volume and the course of the engine power and torque. Each of the measurements was made with using diesel, FAME, fresh vegetable oil and waste vegetable oil.

The measurements were performed with Mercedes 300 D $124 \mathrm{~W}$, a vehicle with inline fuel pump and indirect fuel injection. The construction scheme of fuel system is shown in Fig. 1.

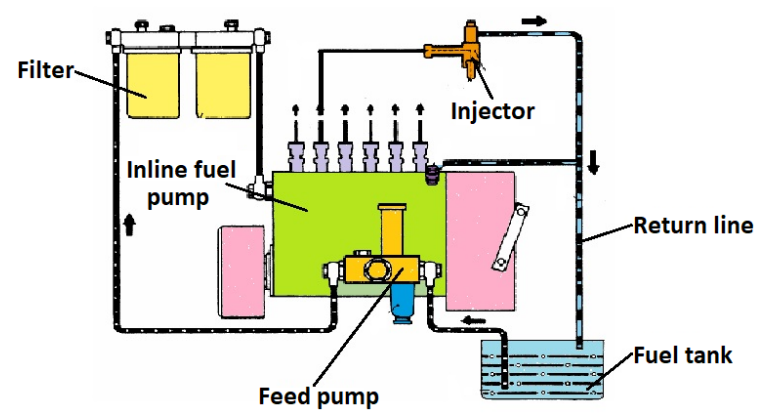

Fig. 1 Inline fuel pump (Janoško et al., 2010)

A fuel is transported via feed pump from the fuel tank trough fuel filters into the high pressure inline fuel pump. Here, the fuel is pressed down to the pressure of about $12 \mathrm{MPa}$ and it is further transported through the high pressure pipes into injectors. These secure a fuel distribution in the distributor pumps. Superfluous fuel is returned back to the fuel tank. In order to prevent particular fuels from being mixed during the measurements, the fuel was transported by fuel can instead of fuel tank, see Fig. 2.

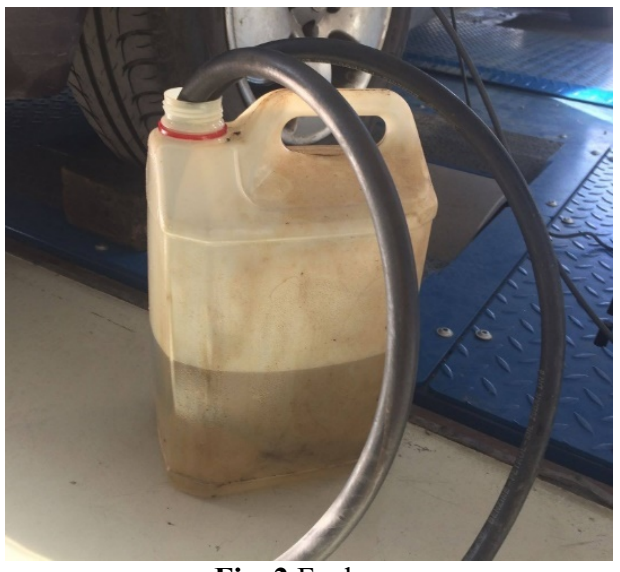

Fig. 2 Fuel can

This way of fuel drawing from a can prevents the measured fuel from being mixed with the others.

The process of fuel replacing was as follows:

- Fuel pump hose was put into to the can with fuel prepared for measuring,

- Hose with superfluous fuel was put into another can,

- Bleeding of fuel system, starting of engine,

- Can was filled up by piping with superfluous fuel of minimum 2 litre volume,

- Return line piping was shifted into the can with fuel prepared for measuring.

Pumping of superfluous fuel from the previous measurement was secured by putting the return line hose into another can. At the same time, only new fuel prepared for particular measuring was transported into the whole fuel system.

Each fuel replacing has the same process.

\subsection{Smoke opacity measurement}

Smoke opacity was measured by MAHA MDO2 LON V 6.11. by free acceleration method. It was measured by the opacimeter that works on the optical principle - the exhaust gases are illuminated by a light, when the value of smoke opacity measured relates to the value of light absorbed.

The method of free acceleration lies in measuring the smoke opacity during the time when a pedal is fully applied up to 1 second, i.e. a full fuel amount is reached. Acceleration pedal is released after the maximum engine speed has been achieved and recorded. The process is repeated 3 times. After that, the arithmetic mean is calculated from the values measured (Kralik, 2019).

\subsection{Exhaust gases composition measurement}

Exhaust gases composition was measured by MAHA MGT 5. The components measured were $\mathrm{CO}$, $\mathrm{HC}, \mathrm{CO}_{2}$ and $\mathrm{NO}_{\mathrm{x}}$. The measurements were performed during simulating a vehicle driving on the cylinder power test station MAHA MSR 1050 at the driving speed of 50 $\mathrm{km} \cdot \mathrm{h}^{-1}$ and $90 \mathrm{~km} \cdot \mathrm{h}^{-1}$. The accuracy of test station's 
measuring is $\pm 2 \%$ (Šarkan et al., 2017). There was used the first gear at both speeds.

Firstly, for a drive simulation, it was necessary to calculate the value of vehicle driving resistances by which the cylinders were braked. Since there was a plane drive at the constant speed chosen, the engine must have overcome the rolling and the air resistances. The value of rolling resistance has been calculated according to following equation:

$$
F_{r}=m \cdot g \cdot f
$$

$F_{r}$ - value of rolling resistance [N]

$m$ - vehicle mass [kg]

$g$ - gravitational acceleration $\left[m . s^{-2}\right]$

$f$ - rolling resistance coefficient [-] (Radosavljevic et al., 2019)

Having the mass of the vehicle in running order of $1,440 \mathrm{~kg}$, the rolling resistance coefficient of vehicle tyres 0.008 has the value of $113 \mathrm{~N}$.

The value of air resistance has been calculated according to the relation:

$$
\begin{aligned}
& F_{a}=0,5 . v^{2} \cdot c_{X} . S \cdot \rho \\
& F_{a}-\text { value of air resistance }[\mathrm{N}] \\
& v-\text { driving speed }\left[\mathrm{m} \cdot \mathrm{s}^{-1}\right] \\
& c_{x} \text { - air resistance coefficient }[-] \\
& S-\text { size of front face }\left[\mathrm{m}^{2}\right] \\
& \rho-\text { air density }\left[\mathrm{kg} \cdot \mathrm{m}^{-3}\right] \text { (Skrúcaný et al., 2016) }
\end{aligned}
$$

Having the speed of $50 \mathrm{~km} \cdot \mathrm{h}^{-1}$ and the air density of $1.29 \mathrm{~kg} \cdot \mathrm{m}^{-3}$, the value of air resistance is $77 \mathrm{~N}$. It is $250 \mathrm{~N}$ when having the speed of $90 \mathrm{~km} \cdot \mathrm{h}^{-1}$.

The calculated values of driving resistances were entered into the cylinder test station computer. The cylinders were subsequently braked by the same value.

The measurement of the exhaust gases composition was performed after the vehicle had been stabilized at the required speed. The driving speed was observed with deviation of $\pm 0.5 \mathrm{~km} \cdot \mathrm{h}^{-1}$.

\subsection{Measurement of the course of the engine power and torque's curves}

The measurements were performed at the cylinder test station MAHA MSR 1050 respecting the fourth transmission gear. The vehicle was fixed on the test station and after the engine had been conditioned at the fourth gear with having the acceleration pedal fully applied, the maximum engine speed was reached and, thus, the engine power was measured. After that, a driver applied the clutch pedal when still using the fourth gear, and let the wheels slow down freely in order to measure the mechanical losses between the engine and cylinders. Then the computer calculated the course of the engine power and torque's curves (MAHA MSR).

\section{Results}

\subsection{Engine smoke opacity}

The Table 1 shows the measured value of engine smoke opacity depending on the fuel used. The first column shows the fuels used during measurements. The second column displays the value of smoke opacity and the third column displays the difference of smoke opacity measured in \% compared with diesel. The last column shows the value of variance which is calculated as the arithmetic mean of deviations between the measurements.

Table 1 Engine smoke opacity depending on the fuel used

\begin{tabular}{|l|l|l|l|}
\hline Fuel & $\begin{array}{l}\text { Smoke } \\
\text { opacity } \\
\mathbf{m}^{-1}\end{array}$ & $\begin{array}{l}\text { Change in the } \\
\text { value compared } \\
\text { with diesel \% }\end{array}$ & $\begin{array}{l}\text { Variance } \\
\mathbf{m}^{-1}\end{array}$ \\
\hline Diesel & 0.64 & 0 & 0.10 \\
\hline FAME & 0.49 & $-23.4 \%$ & 0.08 \\
\hline Fresh oil & 0.40 & $-37.5 \%$ & 0.13 \\
\hline Used oil & 0.38 & $-40.6 \%$ & 0.12 \\
\hline
\end{tabular}

The graph in the Figure 3 also shows the results for its better transparency.

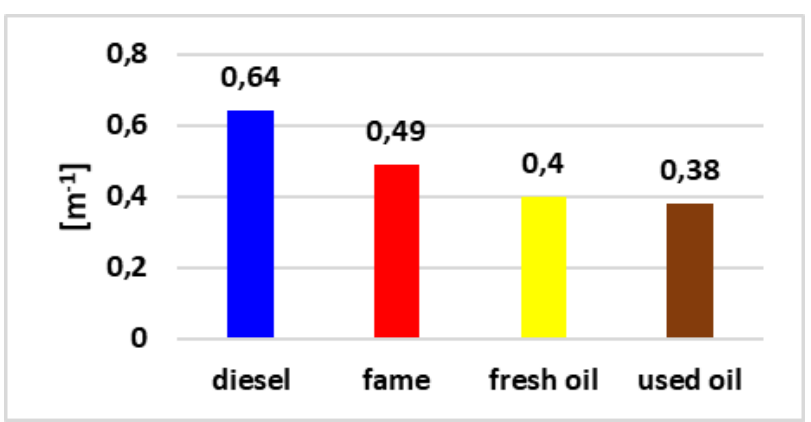

Fig. 3 Engine smoke opacity depending on the fuel used

As seen from the Table 1 and Figure 3, the highest value of smoke opacity was reached during diesel measurement. By using waste oil, the engine smoke opacity reduced up to $40.6 \%$ in comparison with diesel.

\subsection{Exhaust gases composition}

The following part of the article shows the impact of the operation of vehicles fuelled by diesel, FAME, fresh and waste oil on the exhaust gases volume in the engine. The table 2 displays the impact of using particular fuels on the values of $\mathrm{CO}$ and $\mathrm{CO}_{2}$. The results are matched to the driving speeds when being measured. 
Table $2 \mathrm{HC}$ and NOx concentrations in the exhaust gases

\begin{tabular}{|l|l|l|l|l|}
\hline Fuel & $\begin{array}{l}\text { CO } \\
\%\end{array}$ & $\begin{array}{l}\text { Difference } \\
\text { compared } \\
\text { with diesel } \\
\text { \% }\end{array}$ & $\begin{array}{l}\mathbf{C O}_{2} \\
\%\end{array}$ & $\begin{array}{l}\text { Difference } \\
\text { compared } \\
\text { with diesel } \\
\text { \%o }\end{array}$ \\
\hline Diesel & & & & \\
\hline $50 \mathrm{~km} \cdot \mathrm{h}^{-1}$ & 0.02 & 0 & 3.8 & 0 \\
\hline $90 \mathrm{~km} \cdot \mathrm{h}^{-1}$ & 0.02 & 0 & 4.7 & 0 \\
\hline FAME & & & & \\
\hline $50 \mathrm{~km} \cdot \mathrm{h}^{-1}$ & 0.02 & 0 & 4.0 & $+5,3$ \\
\hline $90 \mathrm{~km} \cdot \mathrm{h}^{-1}$ & 0.03 & +50 & 5.2 & +10.6 \\
\hline Fresh oil & & & & \\
\hline $50 \mathrm{~km} \cdot \mathrm{h}^{-1}$ & 0.05 & +150 & 4.4 & +15.8 \\
\hline $90 \mathrm{~km} \cdot \mathrm{h}^{-1}$ & 0.06 & +200 & 5.2 & +10.6 \\
\hline Used oil & & & & \\
\hline $50 \mathrm{~km} \cdot \mathrm{h}^{-1}$ & 0.06 & +200 & 4.5 & +18.4 \\
\hline $90 \mathrm{~km} \cdot \mathrm{h}^{-1}$ & 0.06 & +200 & 5.2 & +10.6 \\
\hline
\end{tabular}

For better transparency, the values of $\mathrm{HC}$ concentration are shown in the form of graph, see Fig. 6

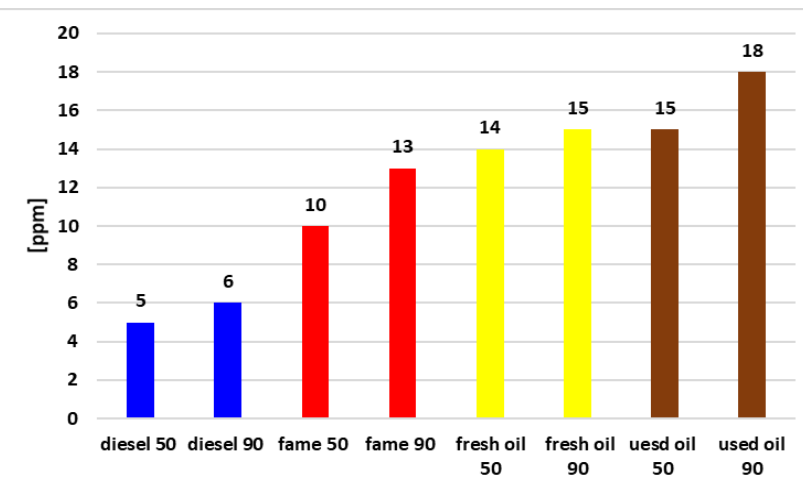

Fig. 4 Values of $\mathrm{HC}$ concentration in the exhaust gases

When using fuels made from oils, HC concentration multiplied.

The Fig. 7 shows the values of $\mathrm{NO}_{\mathrm{x}}$ concentration in the exhaust gases depending on the fuel used.

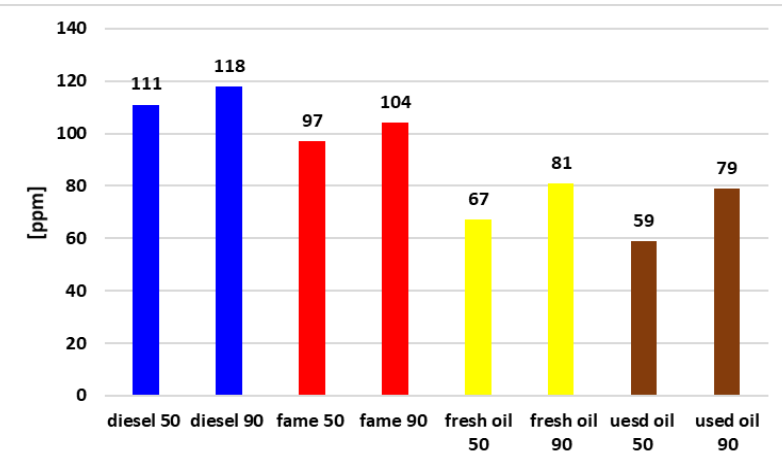

Fig. 5 Values of NOx concentration in the exhaust gases

When using oil based fuels, $\mathrm{NO}_{\mathrm{x}}$ concentration in the exhaust gases decreased.

\subsection{Engine power and torque courses}

The impact of the fuel used on the engine power and torque is shown in the Fig. 8. The graph's horizontal axis displays the engine speed in $\min ^{-1}$, its left vertical axis shows the engine power in $\mathrm{kW}$, and its right vertical axis shows the engine torque in $\mathrm{Nm}$. Orange flatter curves represent the course of torque, and red steeper ones represent the course of the engine power. The course of power's curves on the cylinder test station are in blue, and, between the engine and cylinders are in green.

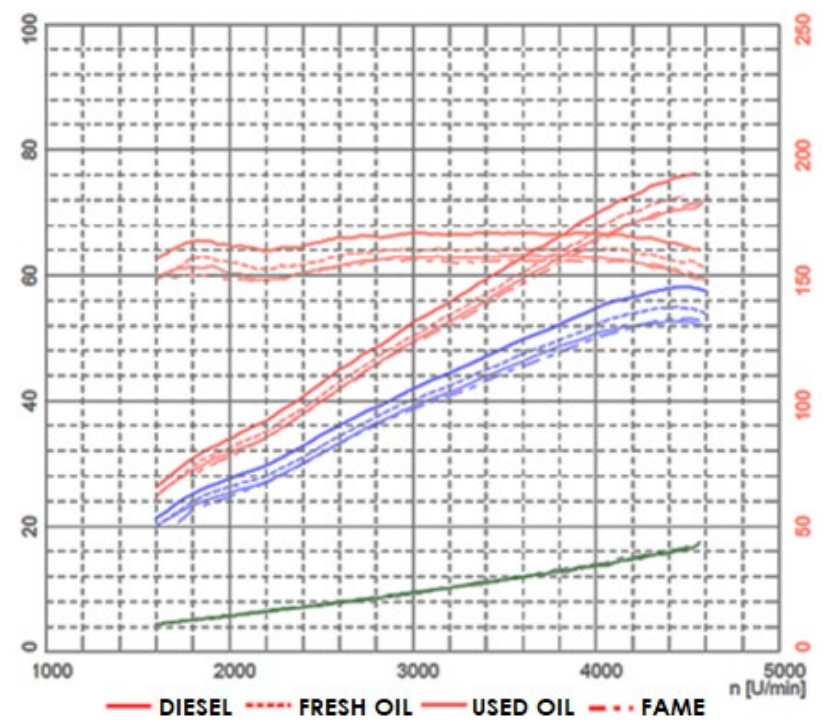

Fig. 6 Impact of fuel on the engine power and torque's courses

As seen from the Figure 8, it can be said that all of the courses are mostly the same. Over the whole measurement, the highest power is seen when using diesel. When using fresh oil, the course of the engine power and torque was lower. When using FAME and waste oil, the curve course was almost identical taking into consideration the deviations of MAHA MSR 1050. The biggest difference in the engine torque was measured when using diesel and FAME at the speed of 1,800 $\mathrm{min}^{-1}$ - $12 \mathrm{Nm}$, power of $5 \mathrm{~kW}$, and the engine speed of 4,200 $\min ^{-1}$.

To understand the impact of fuels used on the vehicle acceleration better, it is possible to make a theoretical calculation of maximum acceleration with using the first gear. The engine torque is important for a maximum possible value of vehicle acceleration. The calculation is therefore made by taking into consideration the engine speed at which the biggest difference of engine torque had been measured.

The first step is to determine the wheel force according to relation:

$$
F_{W}=\left(M_{t} \cdot i_{c} \cdot \eta_{m}\right) / r_{d}
$$

$F_{k}$ - the wheel force [N]

$M_{t}$ - the engine torque [Nm]

$\eta_{m}$ - the mechanical transmission efficiency

$r_{d}$ - the wheel radius [m] (Radosavljevic, 2019) 
The engine torque measured at given speed with using diesel is $162 \mathrm{Nm}$, see Fig 6. The overall transmission ratio when using the first gear is given by relation:

$$
i_{c}=i_{I} \cdot i_{r}
$$

$i_{c}$ - the overall transmission ratio [-]

$i_{I}$ - the transmission ratio at the first gear [-]

$i_{r}$ - the constant transmission ratio in the transfer case [-] (Rievaj et al., 2014)

The value of transmission ratio at the first gear is according to (cars-data) 3.86 and, in the transfer case it is 3.46. The overall transmission ratio at the first gear has the value:

$$
\text { ic }=3.86 \cdot 3.36=13.36
$$

The vehicle has got tyres with size of 195/65 R 15 . The wheel radius is:

$$
r=[2 .(195.0 .65)+(15.25 .4)]: 2=371.3 \mathrm{~mm}(6)
$$

The wheel force is:

$$
F_{W}=162 \cdot 13.86 \cdot 0.90 / 0.37=5246.13 \mathrm{~N}
$$

The maximum possible value of resistance against the acceleration can be calculated using relation:

$$
\begin{aligned}
& F_{a}=F_{W}-F_{V} \\
& F_{a}=5246.13-113=5133.13 \mathrm{~N}
\end{aligned}
$$

Then the maximum vehicle acceleration can be calculated:

$$
a_{\max }=O_{a} / m \cdot \delta
$$

a is the vehicle acceleration $\left[m . \mathrm{s}^{-2}\right]$

$\mathrm{O}_{a}$ is the maximum possible value of resistance against the acceleration

$m$ is the vehicle mass

$\delta$ is the rotational mass coefficient (Synák, 2019)

The calculation of the rotational mass coefficient is time demanding and requires identification of mass and radius of every single rotational component in the engine, between the engine and wheels and between the wheels themselves. In this case, there is no need for so high measurement accuracy. The coefficient value for calculation with using both, diesel and FAME is $\delta=1.45$, according to [9].

The possible vehicle acceleration with diesel used:

$$
a_{\max }=5133.13 / 1440 \cdot 1.45=2.46 m \cdot s^{2}
$$

The maximum theoretical vehicle acceleration when using diesel at the engine speed of 1800 ot. $\mathrm{min}^{-1}$ with the first gear used is $2.46 \mathrm{~m} \cdot \mathrm{s}^{-2}$. By analogical calculation, it is possible to determine that when replacing diesel with fame, under these conditions, the vehicle can have the acceleration of $2.27 \mathrm{~m} . \mathrm{s}^{-2}$. The theoretical difference of vehicle acceleration when using diesel and FAME is 0.19 $\mathrm{m} \cdot \mathrm{s}^{-2}$.

\section{Conclusions}

Using of vegetable oil based fuels does affect the engine smoke opacity, the exhaust gases composition as wells the course of the engine power and torque for little.

The value of smoke opacity measured when using diesel fuel has reached the value of $0.64 \mathrm{~m}^{-1}$, while the maximum permissible value of smoke opacity is $2.50 \mathrm{~m}^{-1}$. Therefore, the engine is able to meet the prescribed emission limits of smoke opacity also after having tested its last 100,000 of kilometres driven. The value of engine smoke opacity also shows the condition of engine and its parts, for example the degree of wear of piston rings, movable components in the injections, and the elements in high pressure pump (Yesilyurt, 2019). In case of these parts being worn out extremely, it could lead to wrong fuel dispersion, or to combustion of engine oil with a fuel, and thus the values of smoke opacity would be substantially higher (Figlus et al., 2016). The measurements have shown a significant reduction of smoke opacity by using fuels made from vegetable oil. Thus, the vehicle is capable to meet the requirements imposed on the smoke opacity during the regular vehicle inspection even when using vegetable based fuels.

Using of fuels made from vegetable oil has also had a significant impact on the exhaust gases composition. $\mathrm{CO}, \mathrm{CO}_{2}$ and $\mathrm{HC}$ concentrations when using these fuels have increased in comparison with the values measured when using diesel oil. $\mathrm{NO}_{\mathrm{x}}$ concentration has decreased when using vegetable based fuels. A possible explanation of such changes in particular exhaust gases components concentrations is that there is a different length of hydrocarbon chain of particular fuels and, probably, the lower heating value of fuels, too (Chand, 2002). Out of these, it can also be concluded the different composition of fuels. While diesel composition is regularly inspected, the other fuels are not. Thus, the composition of vegetable oil based fuels may always vary greatly or little.

When determining the impact of using selected fuels on the course of the engine power and torque curves, the impact of wear was small, even negligible. The highest values of engine power and torque were measured when using diesel, and then with fresh oil and waste oil. The lowest values were measured with FAME used. However, the differences were minimal. The low impact of fuels on vehicle dynamics was also proven by calculation of maximum theoretical vehicle acceleration. Its difference is hardly to recognize, especially from the driver's point of view, bearing in mind that the difference can be only seen in the narrow range of engine. The cylinder test 
station MAHA MSR 1050 also provides a function of measuring the dynamic vehicle acceleration. However, there is no possibility to measure the difference in maximum theoretical acceleration, since the different course of the engine power and torque curves was only in that narrow range of engine speed. When having the acceleration pedal fully applied, the engine speed would have been quickly overcome, and, thus, the acceleration would not have been able to measure. Representing the calculation of possible vehicle acceleration proves that using selected fuels will not cause the deterioration in dynamic vehicle characteristics when having an acceleration pedal fully applied.

\section{Acknowledgment}

This article was created to support project named as: VEGA no. 1/0436/18 - Externalities in road transport, an origin, causes and economic impacts of transport measures.

\section{References}

Cars_data: Online: https://www.cars-data.com/en/mercedesbenz-e-class-1993/1499

Figlus, T., Gnap, J., Skrúcaný, T., Šarkan, B. and Stoklosa, J. 2016. The Use of Denoising and Analysis of the Acoustic Signal Entropy in Diagnosing Engine Valve Clearance. Entropy, 18(7), p.253.

Globalpetrolprices: Online: https://www.globalpetrolprices.com/diesel_prices/

Chand, N., 2002 Plants oils - Fuel of the fitire. In: Journal of Scientific and Industrial Research, 61, pp. $7-16$, ISSN: $0022-4456$

Janoško, I., Polonec, T., Somor, R., 2010, „Electronic Encyklopedia of Contruction Enginec and Vehicles“ In: 41st International Scientific Conference of Czech and Slovak University Departments and Institutions Dealing with the Research of Internal Combustion Engines, 2010, ISBN:978-80-7372-632-4

Karimi, M., Jenkins, B., \& Stroeve, P., 2016, Multi-objective optimization of transesterification in biodiesel production catalyzed by immobilized lipase. Biofuels, Bioproducts And Biorefining, 10(6), 804-818. doi: 10.1002/bbb.1706

Komoditeonline: Online: http://www.komodityonline.com/rastlinne-oleje/

Králik, M., „Method of emission control depending on fuel type and emission system" Online:

https://www.seka.sk/public/files/dokumenty/Emisnakontrola-pravidelna.pdf

MAHA MSR 1050 User manual
Mohadesi, M., Aghel, B., Maleki, M., \& Ansari, A, 2019, Production of biodiesel from waste cooking oil using a homogeneous catalyst: Study of semi-industrial pilot of microreactor. Renewable Energy, 136, 677-682. doi: 10.1016/j.renene.2019.01.039

Radosavljevic, J., Djordjevic, A., Zlatkovic, B., Samardzic, B. 2019 „Compensation of Influence of Protector Compression Coefficients in Tyre Industry“. In: Applied Engineering Letters, Vol. 4, No. 1, pp. 33-39,

Rievaj, V. - Vrábel, J. - Ondruš, J., 2014, Cestné vozidlá. Road vehicles, EDIS - vydavatel'stvo ŽU v Žiline, ISBN $987-$ 80-554-0834

Shim, E., Park, H., \& Bae, C. 2018. Intake air strategy for low $\mathrm{HC}$ and $\mathrm{CO}$ emissions in dual-fuel (CNG-diesel) premixed charge compression ignition engine. Applied Energy, vol. 225, pp. 1068-1077. Doi: 10.1016/j.apenergy.2018.05.060

Skrúcaný, T., Kendra, M., Kalina, T., Jurkovič, M., Vojtek, M. and Synák, F. 2018. Environmental Comparison of Different Transport Modes. Naše more, 65(4), pp.192196.

Skrúcaný, T., Šarkan, B., Gnap, J., 2016, "Influence of Aerodynamic Trailer Devices on Drag Reduction Measured in a Wind Tunnel" In: Eksploatacja I Niezawodnosc - Maintenance and Reliability 2016; 18 (1): 151-154

Synák, F., Rievaj, V., Funtíková, J., Pňaček, M., Kutliak, T., 2018 „EGR and Selected Vehicle Properties, CMDTUR, 2018

Synák, F., Rievaj, V., Gaňa, J.,2019 Liquefied petroleum gas as an alternative fuel, In: Transcom $2019,13^{\text {th }}$ international scientific conference of young scientists and Ph.D. students

Šarkan, B., Stopka, O., 2017, "Quantification of road vehicle performance parameters under laboratory conditions" In: Advances in science and technology - research journal. Vol: 12, pp: 16 - 23, DOI: 10.12913/22998624/92107

Šarkan, B., Stopka, O., Gnap, J., Caban, J. 2016, "Investigation of Exhaust Emissions of Vehicles with Spark Ignition Engine within Emission Control," In: Procedia Engineering, vol. 187, pp. 775-782.

Škorupa, M., Čechovič, T., Kendra, M., Jereb, B. 2018, Case Study of the Impact of the $\mathrm{CO}_{2}$ Emissions Trend from Transport on the External Costs in Slovakia and Slovenia. Transport technic and technology, 14(2), DOI: https://doi.org/10.2478/ttt-2018-0007

Yesilyurt, M. 2019, The effects of the fuel injection pressure on the performance and emission characteristics of a diesel engine fuelled with waste cooking oil biodiesel-diesel blends. Renewable Energy, 132, pp.649-666. 